\title{
Papan Komposit Termoset Serat Sabut Kelapa
}

\section{Composite Board Thermoset Fiber Coconut Fiber}

\author{
Hendri Sawir \\ Staf Pengajar Teknik Lingkungan STTIND Padang \\ Email: hendri.sawir@yahoo.com
}

Naskah Masuk : 19-10-2017 Naskah diterima: 26-10-2017 Naskah disetujui: 21-11-2017

\begin{abstract}
Has been done research of coconut coir waste utilization on making board composite (particle) coco fiber. The results obtained from the coconut fiber coir is in the form of a composite board. The composite board is obtained by determining the length of the coco fiber coir CHF.2 type, determining the many urea formaldehyde type of adhesives. The adhesive for press constancy testing is the FOX glue. For the shine is a melamine formaldehyde type impra. The length of the most suitable coco fiber is to make a composite board of coco fiber is $9 \mathrm{~cm}$ and the use of $10 \%$ urea formaldehide adhesive of the dry weight of the fiber. From the results of this study obtained based on Analysis of Variety (Anova), The resulting composite board meets the SNI standard. No. 03-2105-96, and FAO. 1958. For shine, the best amount of melamine formaldehyde (labur weight) to make a more patterned board is $200 \mathrm{~g} / \mathrm{m} 2$. The physical and mechanical properties of composite boards that have been coated with melamine formaldehide are not observed.
\end{abstract}

Keywords: Waste, coco fiber, composite board.

Abstrak
Telah dilakukan penelitian pemanfaatan limbah sabut kelapa pada pembuatan papan komposit (partikel) serat sabut kelapa. Hasil yang didapatkan dari bagian sabut kelapa yaitu serat sabut adalah dalam bentuk papan komposit. Papan komposit diperoleh dengan menentukan panjang serat sabut kelapa jenis CHF.2, menentukan banyak bahan perekat jenis Urea formaldehyde. Perekat untuk pengujian keteguhan tekan adalah lem FOX. Untuk pengkilapan adalah melamin formaldehide jenis impra. Ukuran panjang serat sabut kelapa yang paling cocok untuk membuat papan komposit dari serat sabut kelapa adalah $9 \mathrm{~cm}$ dan pemakaian perekat urea formaldehide $10 \%$ dari berat kering serat. Dari hasil penelitian ini didapatkan berdasarkan Analisis Ragam (Anova), Papan komposit yang dihasilkan memenuhi standar SNI. No. 03-210596, dan FAO. 1958. Untuk pengkilapan, jumlah (berat labur) melamin formaldehide yang terbaik untuk menjadikan papan lebih bercorak adalah $200 \mathrm{gram} / \mathrm{m}^{2}$. Sifat fisis dan mekanis papan komposit yang telah dilapisi dengan melamin formaldehide tidak diamati.

Kata kunci : Limbah, serat sabut kelapa, papan komposit

\section{PENDAHULUAN}

Potensi sabut kelapa di Sumatera

Barat khususnya kabupaten dan kota

Pariaman sebagai salah satu sentra

kelapa, sampai tahun 2004

berdasarkan data Bapeda, dengan luas

tanam kelapa 31.468 hektar, produksi

buah kelapa 26.587 ton pertahun menghasilkan jumlah sabut kelapa sebanyak $9.305,45$ ton pertahun.

Sabut kelapa merupakan limbah atau hasil samping, dan merupakan bagian yang terbesar dari buah kelapa, yaitu sekitar $35 \%$ dari bobot buah kelapa. Mengingat besarnya limbah sabut kelapa tersebut, maka perlu 
dilakukan upaya pemanfaatan limbah tersebut sebagai bahan baku untuk pembuatan papan komposit.

Sabut kelapa terdiri dari serat dan sabut, yang berupa sabut/gabus hanya $25 \%$ nya dan seratnya $75 \%$ (B.I. SIPUK, 2002). Produk lain yang mungkin dapat dibuat dari serat sabut kelapa adalah papan komposit.

Maloney (1977) mengemukakan bahwa salah satu hal terpenting dalam pembuatan papan komposit adalah jenis bahan (partikel), perekat yang digunakan, alat kempa dan temparatur pengempaan. Menurut Yuliasari (2003) Penggunaan variasi perekat berpengaruh nyata terhadap daya serap air dan sifat fisis dan mekanis papan komposit. Semakin besar komposisi Urea Formaldehid (UF) dalam perekat, sifat fisis dan mekanis papan komposit semakin baik. Dalam penelitian ini akan dipelajari salah satu faktor penting dalam pembuatan papan partikel dari serat sabut kelapa, yaitu ukuran serat dan banyak perekat. Tujuanya adalah guna menetapkan ukuran panjang serat dan banyak perekat yang paling cocok dalam pembuatan papan partikel, sehingga bernilai ekonomi dan bercorak alami, datar, dan licin.
Untuk pembuatan papan komposit termoset dari serat sabut kelapa ini, digunakan Urea formaldehyde (UF) sebagai perekat. Perekat urea formaldehid merupakan perekat sintetis yang digolongkan ke dalam perekat thermosetting. Perekat UF tahan terhadap air dingin, dan panas dalam waktu terbatas serta tidak tahan terhadap air yang sedang mendidih. Perekat ini juga mempunyai ketahanan yang baik sekali terhadap pelarut organik tetapi tidak tahan terhadap asam dan basa kuat (Rayner 1965 cit Supiana, 1995).

Tujuan Penelitian

1. Untuk mengetahui panjang serat dan banyaknya perekat urea formaldehide yang paling cocok untuk membuat papan partikel dari serat sabut kelapa.

2. Untuk mengetahui banyaknya perekat urea formaldehide yang paling cocok untuk membuat papan partikel dari serat sabut kelapa.

\section{METODOLOGI}

\section{Tempat dan Waktu}

Penelitian ini dilakukan di KUD Cubadak Aie Kota Pariaman (Sentra Kelapa), Laboratorium Proses 
Produksi, Fakultas Teknik; dingin dan kempa panas, gelas piala,

Laboratorium Kehutanan, Fa-kultas gergaji potong, caliper, alat uji sifat

Kehutanan, Universitas

fisis dan mekanis dan lain-lain.

Muhammadiyah Sumatera Barat dan

Laboratorium Politeknik, Universitas

Andalas, Padang dari bulan Oktober

2006 sampai dengan bulan Juni 2007.

\section{Bahan dan Alat Penelitian}

Bahan yang digunakan dalam penelitian ini adalah partikel serat sabut kelapa jenis CHF 2. Yaitu serabut kelas 2 diperoleh dari sabut kelapa tua dan sabut kelapa coklat, serabut agak bersih dengan panjang tidak kurang dari $12 \mathrm{~cm}$, warna dari coklat terang ke coklat gelap, jaringan dari pada serabut gelap liat, kuat dan lentur. Serat sabut kelapa tersebut didapatkan dari usaha pengolahan sabut kelapa Kota Pariaman. Perekat yang digunakan adalah perekat jenis urea formaldehida dengan kode UA125 warna putih dengan kadar resin $50 \%$. Pengeras (hardener) yang digunakan adalah $\mathrm{NH} 4 \mathrm{Cl}$. Perekat untuk pengujian keteguhan tekan adalah lem FOX. Sedangkan alat-alat yang akan digunakan antara lain: gelas ukur, elenmeyer, termometer, gunting, baskom, timbangan, ember plastik, oven desikator, cetakan, alat kempa

\section{Cara Penelitian}

Bahan Serat sabut kelapa dipotong sesuai dengan rancangan adalah $3 \mathrm{~cm}, 5 \mathrm{~cm}, 7 \mathrm{~cm}$ dan $9 \mathrm{~cm}$, kemudian dikeringkan sampai mencapai kadar air konstan. Berat serat yang dibutuhkan untuk ukuran papan partikel $30 \mathrm{~cm}$ x $30 \mathrm{~cm}$ dengan ketebalan $1 \mathrm{~cm}$ dan kerapatan 0,7 $\mathrm{g} / \mathrm{cm}^{3}$ adalah 630 gram. Jumlah perekat urea formaldehida sesuai dengan rancangan adalah $10 \%, 12 \%$, $14 \%$ dari berat kering serat dengan pedoman aturan FAO.(1958) yaitu 4$15 \%$ dari berat kering partikel.

Pencampuran serat dengan perekat dilakukan secara manual sampai rata, kemudian dituang ke dalam cetakan. Setelah adonan dimasukkan ke dalam cetakkan, kemudian dilakukan penekanan dengan kempa dingin sebagai penekanan pendahuluan sampai terbentuk mat partikel. Pengempaan panas dilakukan dengan suhu kempa $120{ }^{\circ} \mathrm{C}$ dan tekanan 10 $\mathrm{kg} / \mathrm{cm}^{2}$ hingga ketebalan $\pm 1 \mathrm{~cm}$ selama 10 menit. Selesai pengempaan maka terbentuk papan komposit. 
Kemudian papan partikel tersebut dikondisikan selama \pm 14 hari untuk mencapai kadar air kesetimbangan (kadar air lingkungan) pada suhu 25 ${ }^{\circ} \mathrm{C}$ pada kelembapan $27 \mathrm{~g} / \mathrm{m}^{3}$. yang dilakukan di Laboratorium Proses Produksi, Universitas Muhammadiyah Sumatera Barat.

\section{Data Yang diamati}

Pengujian papan komposit dilakukan terhadap papan tanpa mendapat perlakuan permukaan, yang meliputi pengujian sifat fisik dan mekanik dengan ketentuan dan aturan menurut ASTM (American Society for Testing and Material) bagian 16 dalam Designation 1037-64 yaitu Standart Me- thode of Evaluating The Properties of Wood Base Fiber and Particle Panel Material (Anonim, 1974) Mutu yang disyaratkan oleh Dewan Standarisasi Nasional Indonesia (SNI1996) dan FAO (1958) untuk papan partikel datar adalah seperti yang terdapat dalam Tabel 1.

Dengan contoh uji papan komposit seperti yang terdapat dalam Gambar 1. Sifat yang diuji antara lain sifat fisik (Kadar Air, Kerapatan, Daya Serap Air, Pengembangan Tebal), dilakukan di Laboratorium Proses Produksi,
Universitas Muhammadiyah Sumatera Barat, sifat mekanik (Keteguhan Patah/MOR, Keteguhan Tekan Sejajar Permukaan, Keteguhan Rekat/ internal bond).

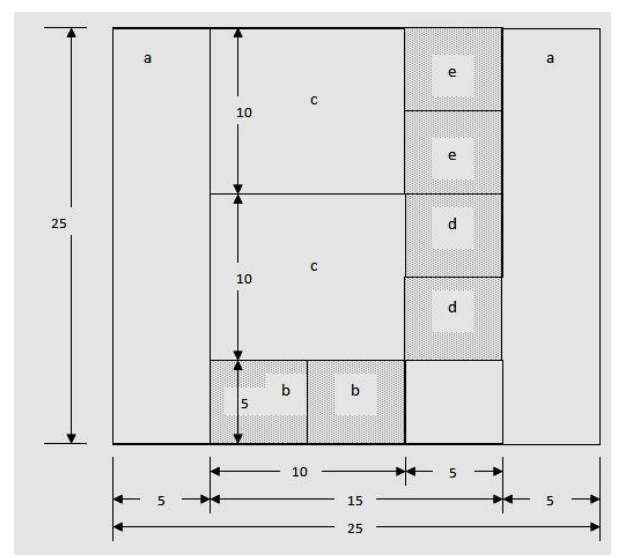

Gambar 1. Cara pengambilan contoh uji sifat fisik dan mekanik papan komposit serat sabut kelapa dengan ukuran $25 \mathrm{~cm} \times 25 \mathrm{~cm}$ (ASTM D 1037); (a). contoh uji untuk keteguhan (modolus) patah $25 \times 5 \mathrm{~cm}$, (b). contoh uji kadar air dan kerapatan $5 \times 5 \mathrm{~cm}$, (c). contoh uji daya serap air dan pe-ngembangan tebal $10 \times 10 \mathrm{~cm}$, (d). contoh uji kekuatan tekan dan kerapatan $5 \times 5 \mathrm{~cm}$, (d). contoh uji untuk internal bond $5 \times 5 \mathrm{~cm}$.

Tabel 1. Standarisasi Nasional Indonesia (1996) dan FAO (1958)

\begin{tabular}{llll}
\hline $\mathrm{N}_{0}$ & SNI. N0. 03-2105-96 & FA0. 1958 \\
\hline 1 & Kadar air & $14 \%$ & Tidak disyaratkan \\
2 & Kerapatan & $0,50-0,90 \mathrm{~g} / \mathrm{cm}^{3}$ & $0,4-0,8 \mathrm{~g} / \mathrm{cm}^{3}$ \\
3 & Daya Serap Air & Max. $35 \%$ & $20-75 \%$ \\
4 & Pengembangan Tebal & Max. $12 \%$ & Tidak disyaratkan \\
5 & KeteguhanRekat Intemal & Minimum $6 \mathrm{~kg} \mathrm{~cm}^{2}$ & Min. $2-12 \mathrm{~kg} / \mathrm{cm}^{2}$ \\
6 & Keteguhan Patah(MOR) & $80 \mathrm{~kg} \mathrm{~cm}^{2}$ & $100-500 \mathrm{~kg} \mathrm{~cm}^{2}$ \\
7 & Modolus Tekan & Tidak disyaratkan & $100-200 \mathrm{~kg} \mathrm{~cm}^{2}$ \\
\hline & & & pengujian
\end{tabular}
keteguhan tekan adalah lem FOX. Bahan pengeras yang digunakan $\mathrm{NH} 4 \mathrm{Cl}$ dengan jumlah $1 \%$ dari berat masing-masing perekat. dilakukan di Laboratorium Politeknik, Universitas Anda- las, Padang. 
Papan komposit yang telah Analisis Ragam (Univariate Analisis memenuhi standar selanjutnya dilapisi dengan melamin formaldehida berdasarkan berat labur yaitu berkisar antara 190-200 g/m² (Pasrul, 1991). Sifat fisis dan mekanis papan komposit yang telah dilapisi dengan melamin formaldehide tidak diamati.

Rancangan percobaan penelitian ini dilakukan dengan menggunakan metode experimental (percobaan labor) dengan Rancangan Percobaan dalam bentuk Faktorial A X B (Pratisto A, 2004). Faktor pertama (A) adalah panjang sabut yang terdiri dari empat taraf yaitu: $3 \mathrm{~cm}, 5 \mathrm{~cm}, 7 \mathrm{~cm}, 9 \mathrm{~cm}$. Faktor (B) adalah jumlah perekat yang terdiri dari tiga taraf yaitu: $10 \%, 12 \%$, $14 \%$ dari berat kering serat, masingmasing perlakuan men- dapat 3 kali ulangan seperti yang terdapat dalam Tabel 2.

Tabel 2. Perlakuan dan kebutuhan bahan papan komposit

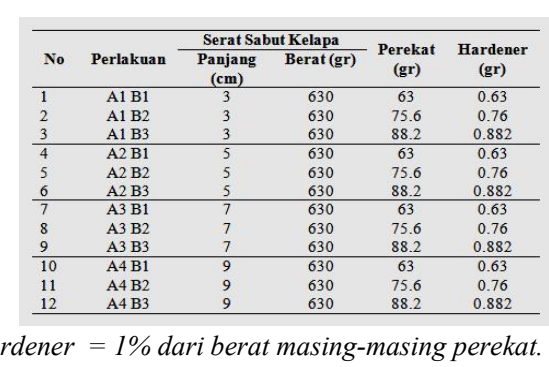

Hasil perhitungan diatas, dimasukkan kedalam tabel SPSS Data Editor, kemudian dilanjutkan dengan

of Variance), apabila pada Anova didapatkan perbedaan yang nyata, maka hasil pengamatan dilanjutkan dengan Uji lanjut Duncan's (Post Hoc Test), uji beda nyata (Pratisto, 2004).

\section{HASIL DAN PEMBAHASAN}

Sifat fisika dan mekanika papan komposit merupakan parameter yang cukup baik untuk menduga kualitas papan komposit yang dihasilkan. Dewan Standarisasi Nasional Indonesia (SNI-1996) dan FAO (1958) menetapkan persyaratan sifat fisik dan mekanik papan komposit yang harus dipenuhi, seperti yang terlihat dalam Tabel 1.

\section{Sifat fisik papan komposit}

\section{Kadar Air Kesetimbangan Papan} Komposit

Dari hasil pengujian terhadap kadar air kesetimbangan rata-rata papan komposit serat sabut kelapa berkisar antara $6,01 \%$ sampai 8,69\%, nilai kadar air kesetimbangan tertinggi terda pat pada panjang serat $3 \mathrm{~cm}$ dan banyak perekat $14 \%$. Nilai kadar air kesetimbangan terendah terdapat pada panjang serat 9 $\mathrm{cm}$ dan banyak perekat $12 \%$. Rata- 
rata kadar air kesetimbangan terlihat dalam Tabel 3. dan lebih dijelaskan dengan grafik seperti yang terdapat dalam Gambar 2. Kadar air kesetimbangan diamati pada ruang yang suhunya $25^{\circ} \mathrm{C}$ pada kelembapan $27 \mathrm{~g} / \mathrm{m}^{3}$.

Tabel 3. Nilai rata-rata kadar air kesetimbangan papan komposit serat sabut kelapa, pada ukuran panjang serat dan banyak perekat yang berbeda ( \%).

\begin{tabular}{lccc}
\hline & \multicolumn{3}{c}{ Banyak Perekat } \\
\cline { 2 - 4 } Panjang Serat & B1 (10\%) & B2 $(\mathbf{1 2} \%)$ & B3 (14\%) \\
\hline A1 (3cm) & 7,43 & 7,90 & 8,69 \\
A2 (5cm) & 7,24 & 8,37 & 8,40 \\
A3 (7cm) & 7,71 & 7,46 & 8,28 \\
A4 (9cm) & 7,69 & 6,01 & 7,20 \\
\hline
\end{tabular}

Sumber : Hasil Analisis

Apabila dibandingkan dengan standar SNI, maka nilai kadar air kesetimbangan yang diperoleh semuanya telah memenuhi standar tersebut, karena SNI.(1996) mensyaratkan nilai kadar air maksimum $14 \%$ untuk FAO. (1958) tidak disyaratkan.

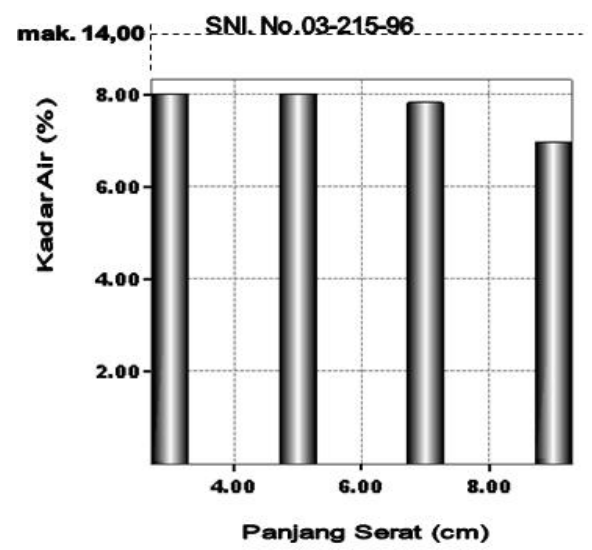

Gambar 2a. Grafik intereaktif variabel panjang serat kadar air kesetimbangan papan komposit

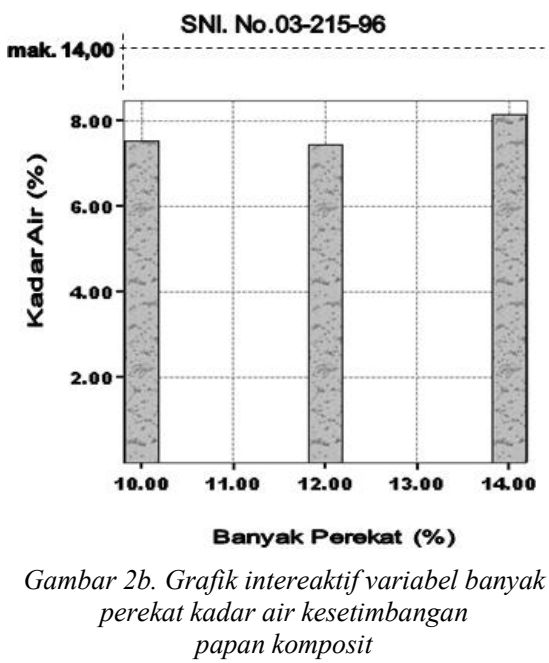

Selanjutnya untuk mengetahui pengaruh panjang serat, banyak perekat dan intereaksi antara panjang serat-jumlah perekat terhadap kadar air, maka dilakukan analisis ragam. Dari analisis ragam tersebut menunjukkan tidak ada pengaruh (signifikan) ukuran panjang serat, banyak perekat dan intereaksi keduanya terhadap kadar air.

Hal ini disebabkan karena kadar air papan komposit lebih kecil dari kadar air bahan baku. Kollman dkk (1975), mengemukakan bahwa kadar air papan komposit lebih rendah dari kadar air bahan bakunya dan faktor lingkungan sangat mempengaruhi. Faktor-faktor yang mungkin menyebabkan kadar air papan komposit lebih rendah dari bahan baku adalah faktor perekat, dimana rongga-rongga didalam papan partikel 
makin kecil (tertutup) akibat masuknya perekat ke dalam pori-pori partikel, kemudian akibat pemberian panas pada proses pengempaan akan dapat men gubah struktur pada dinding sel sehingga partikel-partikel tidak lagi higrokopis dengan demikian akan menyerap air lebih sedikit dari lingkungan. Kadar air papan komposit tergantung pada kondisi udara sekelilingnya karena papan koposit ini terdiri atas bahan-bahan yang mengandung lignoselulosa yang bersifat higrokopis. Kadar air papan komposit akan semakin rendah dengan semakin banyaknya perekat yang digunakan karena kontak antar partikel akan semakin rapat, sehingga air akan sulit untuk masuk di antara partikel kayu (Widarmana, 1977).

\section{Kerapatan Papan komposit}

Dari hasil pengujian terhadap kerapatan rata-rata papan komposit serat sabut kelapa berkisar antara $0,64 \mathrm{~g} / \mathrm{cm}^{3}$ sampai $0,74 \mathrm{~g} / \mathrm{cm}^{3}$, nilai kerapatan tertinggi terdapat pada panjang serat dengan ukuran $(9 \mathrm{~cm})$ dan banyak perekat sebesar (14\%). Nilai kerapatan terendah terdapat pada panjang serat $(5 \mathrm{~cm}$ dan $7 \mathrm{~cm})$ kemudian dengan banyak perekat
(12\% dan 14\%). Namun secara umum nilai rata-rata kerapatan terendah terdapat pada panjang serat $(3 \mathrm{~cm})$. Rata-rata kerapatan terlihat dalam Tabel 4. dan lebih dijelaskan dengan grafik seperti yang terdapat dalam Gambar 3.

Tabel 4. Nilai rata-rata kerapatan papan komposit dari sabut kelapa, pada ukuran panjang serat dan banyak perekat yang berbeda $\left(\mathrm{g} / \mathrm{cm}^{3}\right)$.

\begin{tabular}{|c|c|c|c|}
\hline \multirow{2}{*}{$\begin{array}{c}\text { Panjang } \\
\text { Serat }\end{array}$} & \multicolumn{3}{|c|}{ Banyak Perekat } \\
\hline & B1 $(10 \%)$ & B2 (12\%) & B3 $(14 \%)$ \\
\hline A1 (3cm) & 0,65 & 0,66 & 0,66 \\
\hline A2 (5cm) & 0,67 & 0,64 & 0,67 \\
\hline A3 (7cm) & 0,71 & 0,64 & 0,64 \\
\hline A4 (9cm) & 0,71 & 0,70 & 0,74 \\
\hline
\end{tabular}

Sumber : Hasil Analisis

Apabila dibandingkan dengan standar SNI (1996) dan FAO (1958), maka semua nilai kerapatan yang diperoleh telah memenuhi standar tersebut, karena SNI (1996) mensyaratkan nilai kerapatan 0,50 $0.90 \mathrm{~g} / \mathrm{cm}^{3}$ dan FAO. 1958 mensyaratkan nilai kerapatan 0,40 $0.80 \mathrm{~g} / \mathrm{cm}^{3}$.

Selanjutnya untuk mengetahui pengaruh panjang serat, banyak perekat dan intereaksi antara panjang serat-banyak perekat terhadap kerapatan, maka dilakukan analisis ragam. Dari analisis ragam tersebut menunjukkan tidak ada pengaruh (signifikan) panjang serat, banyak perekat dan intereaksi keduanya 
terhadap kerapatan. Disamping itu ukuran panjang serat dengan ukuran $(9 \mathrm{~cm})$ mempunyai nilai kerapatan yang paling baik. Hal ini disebabkan karena semakin panjang ukuran serat semakin baik kerapatannya. Untuk memperoleh nilai kerapatan yang baik, ukuran sabut yang digunakan sebaiknya tidak kurang dari ukuran (9 $\mathrm{cm})$ supaya hasil yang diperoleh sesuai dengan yang diinginkan.

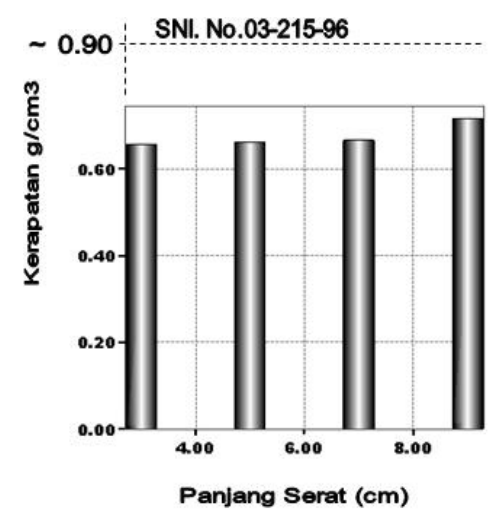

Gambar 3a. Grafik intereaktif variabel panjang serat kerapatan papan komposit

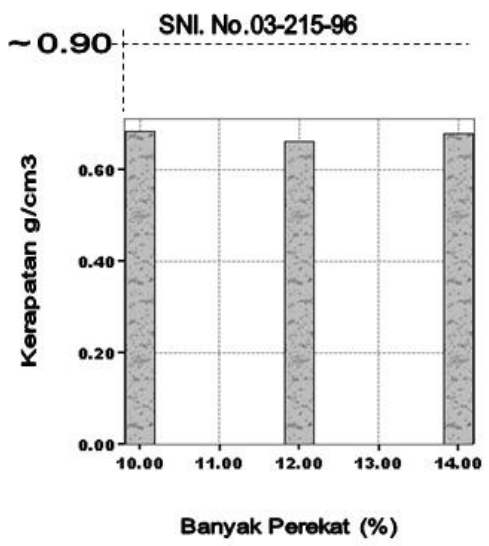

Gambar 3b. Grafik intereaktif variabel banyak perekat kerapatan papan partikel

Disamping itu pemakaian jumlah perekat tidak terlalu mempengaruhi terhadap kerapatan. Menurut Maloney
(1977), faktor-faktor yang mempengaruhi sifat papan partikel diantaranya jenis dan ukuran partikel, teknik pembuatan, kadar air dari bahan yang sedang dikerjakan dan jumlah perekat. Widarmana (1977) me-nyatakan kerapatan papan partikel adalah suatu ukuran kekompakan partikel dalam suatu lembaran dan sangat tergantung pada kayu asal yang digunakan serta besarnya tekanan yang diberikan selama pengempaan. Semakin tinggi nilai kerapatan papan partikel yang dibuat maka semakin besar pula tekanan yang digunakan pada saat pengempaan.

\section{Daya Serap Air Papan Partikel}

Dari hasil pengujian terhadap daya serap air rata-rata papan komposit serat sabut kelapa berkisar antara (41,81\% sampai 58,69\%), nilai daya serap tertinggi terdapat pada panjang serat $(3 \mathrm{~cm})$ dan banyak perekat $(10$ \%). Nilai daya serap terendah terdapat pada panjang serat $(9 \mathrm{~cm})$ dan banyak perekat $(14 \%)$. Rata-rata daya serap terlihat dalam Tabel 5. dan lebih dijelaskan dengan grafik seperti yang terdapat dalam Gambar 4.

Tabel 5. Nilai rata-rata daya serap air papan komposit serat sabut kelapa, pada ukuran panjang serat dan banyak perekat yang berbeda ( \%). 


\begin{tabular}{cccc}
\hline \multirow{3}{*}{$\begin{array}{c}\text { Banjang } \\
\text { Serat }\end{array}$} & \multicolumn{3}{c}{ Banyak Perekat } \\
\cline { 2 - 4 } & B1 (10\%) & B2 (12 \%) & B3 (14\%) \\
\hline A1 (3cm) & 58,69 & 47,83 & 50,04 \\
A2 (5cm) & 52,35 & 53,16 & 50,56 \\
A3 (7cm) & 53,48 & 47,84 & 49,46 \\
A4 (9cm) & 49,97 & 47,33 & 41,81 \\
\hline
\end{tabular}

Sumber : Hasil Analisis

Apabila dibandingkan dengan standar FAO (1958), maka nilai daya serap air yang diperoleh telah memenuhi standar tersebut, karena FAO (1958) mensyaratkan nilai daya serap air $20 \%$ sampai $75 \%$.

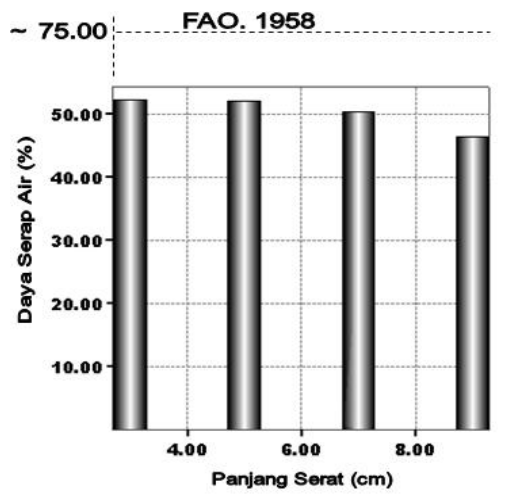

Gambar 4a. Grafik intereaktif variabel panjangserat daya serap air papan komposit

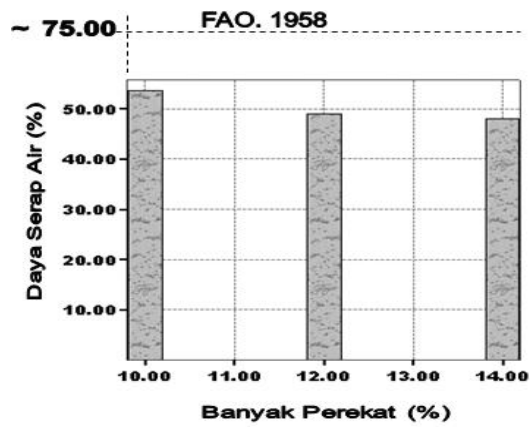

Gambar 4b. Grafik intereaktif variabel banyak perekat daya serap air papan komposit

Untuk mengetahui pengaruh panjang serat, banyak perekat dan intereaksi antara panjang serat-banyak perekat terhadap daya serap air, maka dilakukan analisis ragam. Dari analisis ragam tersebut menunjukkan tidak ada perbedaan yang nyata pada panjang serat sedangkan untuk banyak perekat mempunyai pengaruh yang berbeda (signifikan) terhadap daya serap air akan tetapi intereaksi keduanya tidak berbeda nyata. Hasil Uji lanjut Duncan's (Post Hoc Test) uji beda nyata untuk banyak perekat dapat dilihat pada Tabel 6 .

Tabel 6. Perbedaan banyak perekat dalam mempengaruhi daya serap air.

\begin{tabular}{lc}
\hline \multicolumn{1}{c}{ Perlakuan } & Daya serap air (\%) \\
\hline Banvakperekat & $53,62 \mathrm{a}$ \\
B1. $(63,0 \mathrm{~g})$ & $49,04 \mathrm{~b}$ \\
B2. $(75,6 \mathrm{~g})$ & $47,98 \mathrm{~b}$ \\
B3. $(88,2 \mathrm{~g})$ &
\end{tabular}

Angka-angka yang ditulis dengan huruf kecil yang sama pada lajur, berbeda tidak nyata menurut DMNRT taraf $5 \%$

Dari Tabel 6 memperlihatkan daya serap air papan komposit terendah terdapat banyak perekat $(88,2 \mathrm{~g}$ dan $75,6 \mathrm{~g})$ berbeda nyata (signifikan) dengan perlakuan banyak perekat (63 g). Hal ini dapat terjadi karena semakin banyak perekat akan dapat memaksimumkan penutupan ronggarongga kosong serta pori-pori yang ada pada papan komposit sehingga untuk daya serap air akan lebih kecil. Halligan (1970), mengemukakan bahwa daya serap air papan komposit dipengaruhi oleh volume ruang kosong antara partikel dan luas permukaan yang tertutupi perekat. 


\section{Pengembangan tebal Papan}

\section{Partikel}

Dari hasil pengujian terhadap pengem bangan tebal rata-rata papan partikel sabut kelapa berkisar antara $(9,05 \%$ sampai $19,38 \%)$, nilai pengembangan tebal tertinggi terdapat pada panjang serat $(3 \mathrm{~cm}$ dan banyak perekat 14\%). Nilai pengembangan tebal terendah terdapat pada panjang serat $9 \mathrm{~cm}$ dan banyak perekat (14\%). Rata-rata pengembangan tebal terlihat dalam Tabel 7. dan lebih dijelaskan dengan grafik seperti yang terdapat dalam Gambar 5.

Tabel 7. Nilai rata-rata pengembangan tebal papan komposit dari sabut kelapa, pada ukuran panjang serat dan banyak perekat yang berbeda ( \%).

\begin{tabular}{lccc}
\hline & \multicolumn{3}{c}{ Banyak Perekat } \\
\cline { 2 - 4 } Panjang Serat & B1 (10\%) & B2 (12 \%) & B3 (14\%) \\
\hline A1 (3cm) & 16,81 & 14,37 & 19,38 \\
A2 (5cm) & 16,42 & 14,08 & 19,22 \\
A3 (7cm) & 14,95 & 18,75 & 14,32 \\
A4 (9cm) & 11,99 & 11,28 & 9,05 \\
\hline
\end{tabular}

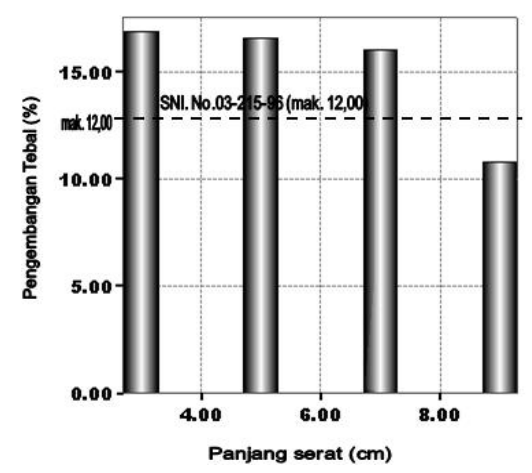

Gambar 5a.Grafik intereaktif variabel panjang serat pengembangan tebal papan komposit

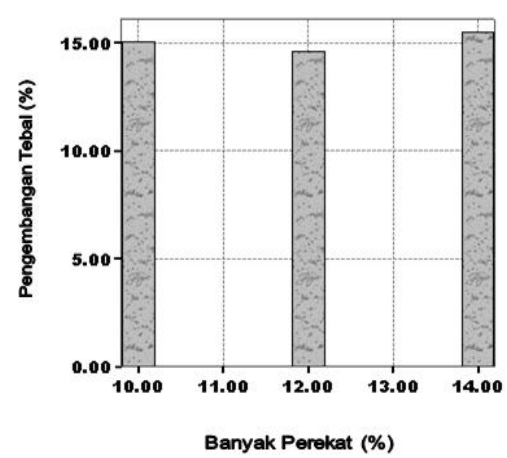

Gambar 5b. Grafik intereaktif variabel banyak perekat pengembangan tebal papan komposit

Apabila dibandingkan dengan standar SNI (1996), maka nilai pengembanan tebal yang diperoleh hanya panjang serat $(9 \mathrm{~cm})$ dengan banyak perekat $(10 \%, 12 \%$, dan 14 \%) yang memenuhi standar, karena SNI (1996) mensyaratkan nilai kadar air maksimum $12 \%$ untuk FAO (1958) (tidak disyaratkan). Sedangkan ukuran serat $(7 \mathrm{~cm}, 5 \mathrm{~cm}$ dan $3 \mathrm{~cm})$ dengan banyak perekatnya belum memenuhi standar karena nilainya melebihi (12 $\%)$.

Untuk mengetahui pengaruh panjang serat, banyak perekat dan intereaksi antara panjang serat-banyak perekat terhadap pengembangan tebal, maka dilakukan analisis ragam. Dari analisis ragam tersebut menunjukkan perbedaan yang sangat nyata (signifikan) pada ukuran panjang serat sedangkan untuk banyak perekat dan intereaksi keduanya tidak berbeda nyata dalam mempengaruhi 
pengembangan tebal. Hasil Uji lanjut Post Hoc Test (uji beda nyata) untuk perbedaan panjang serat dan banyak perekat tercantum dalam Tabel 8 .

Tabel 8. Perbedaan ukuran panjang serat dalam mempengaruhi pengembangan tebal papan komposit (\%).

\begin{tabular}{lccc}
\hline & \multicolumn{3}{c}{ Banyak Perekat } \\
\cline { 2 - 4 } Panjang Serat & B1 (10\%) & B2 (12 \%) & B3 (14 \%) \\
\hline Al (3cm) & 16,81 & 14,37 & 19,38 \\
A2 (5cm) & 16,42 & 14,08 & 19,22 \\
A3 (7cm) & 14,95 & 18,75 & 14,32 \\
A4 (9cm) & 11,99 & 11,28 & 9,05 \\
\hline
\end{tabular}

Angka-angka yang ditulis dengan huruf kecil yang sama pada lajur, berbeda tidak nyata menurut DMNRT taraf $5 \%$

Dari Tabel 8. memperlihatkan pengem- bangan tebal papan komposit terendah terdapat pada panjang serat $(9 \mathrm{~cm})$ berbeda sangat nyata dengan perlakuan ukuran partikel lain. Hal ini dapat terjadi karena pengaruh panjang serat yang digunakan, semakin panjang ukuran serat maka berkemungkinan pori-pori yang ditutupi perekat semakin kecil, sebaiknya sabut tersebut tidak usah dipotong kurang dari $(9 \mathrm{~cm})$ supaya mempunyai pengembangan tebal yang sedikit. Ukuran serat yang lainya mengandung pori-pori yang lebih banyak, sehingga air lebih cendrung untuk dapat ditarik ke dalam pori-pori papan partikel. Dan akibatnya air yang di-serap lebih banyak dan berdampak pada pengembangan tebal yang cukup besar. Halligan mengemukakan bahwa penyerapan air papan komposit dipengaruhi oleh volume ruang kosong diantara partikel dan luas permukaan yang tertutupi perekat. Semakin tinggi jumlah perekat yang digunakan maka rongga kosong dan permukaan partikel semakin tertutup sehingga untuk dimasuki air semakin kecil. Widarmana, 1977 cit Yustrivikasi (2002), menyatakan bahwa penambahan kadar perekat akan memperbaiki sifat-sifat papan komposit. Salah satu kelemahan papan partikel adalah besarnya tingkat pengembangan tebal. Pengembangan tebal ini akan menurun dengan semakin banyak parafin yang ditambahkan dalam proses pembuatannya, sehingga sifat kedap air akan lebih sempurna (FAO (1958) dalam Supiana 1995).

Menurut Lasmini (1982), dari uji regresi yang dilakukan terdapat hubungan yang positif antara pegembangan tebal dengan penyerapan air papan partikel, semakin besar penyerapan air maka semakin besar pula pengembangan tebal papan komposit. 
Sifat mekanik papan partikel

1. Keteguhan patah / MOR Papan

\section{Komposit}

Dari hasil pengujian terhadap keteguhan patah rata-rata papan partikel sabut kelapa berkisar antara $\left(79,81 \mathrm{~kg} / \mathrm{cm}^{2}\right.$ sampai $\left.157,95 \mathrm{~kg} / \mathrm{cm}^{2}\right)$, nilai keteguhan patah tertinggi terdapat pada panjang serat $(5 \mathrm{~cm})$ dan banyak perekat (14 \%). Nilai keteguhan patah terendah terdapat pada panjang serat $(3 \mathrm{~cm})$ dan banyak perekat (12\%). Namun secara umum nilai rata-rata keteguhan patah tertinggi terdapat pada panjang serat (9 cm). Rata-rata keteguhan patah terlihat dalam Tabel 9. dan lebih dijelaskan dengan grafik seperti yang terdapat dalam Gambar 6a dan $6 b$.

Tabel 9. Nilai rata-rata keteguhan patah papan komposit dari sabut kelapa, pada ukuran panjang serat dan banyak perekat yang berbeda $\left(\mathrm{kg} / \mathrm{cm}^{2}\right)$.

\begin{tabular}{lccc}
\hline \multirow{3}{*}{ Panjang Serat } & \multicolumn{3}{c}{ Banyak Perekat } \\
\cline { 2 - 4 } & B1 $(\mathbf{1 0} \%)$ & B2 $(\mathbf{1 2} \%)$ & B3 (14\%) \\
\hline Al $\mathbf{3} \mathbf{c m})$ & 114,09 & 79,81 & 135,34 \\
A2 (5cm) & 84,42 & 88,90 & 157,95 \\
A3 (7cm) & 125,21 & 112,04 & 94,87 \\
A4 (9cm) & 142,26 & 144,41 & 103,92 \\
\hline
\end{tabular}

Sumber : Hasil Analisis

Apabila dibandingkan dengan standar SNI (1996), maka rata-rata nilai keteguhan patah yang diperoleh telah memenuhi standar tersebut, karena SNI (1996) mensyaratkan nilai keteguhan patah $\left(80 \mathrm{~kg} / \mathrm{cm}^{2}\right)$ sedangkan FAO (1958) mensyaratkan nilai keteguhan patah $(100-500$ $\mathrm{kg} / \mathrm{cm}^{2}$

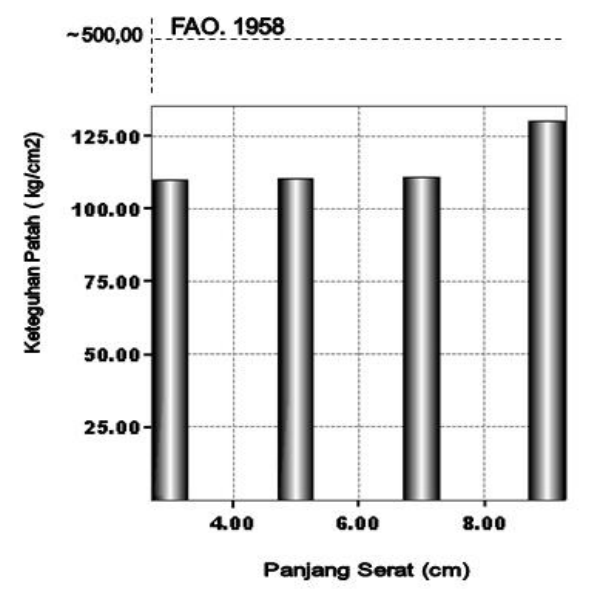

Gambar 6a. Grafik intereaktif variabel panjang sabut keteguhan patah/MOR papan komposit

Untuk mengetahui pengaruh panjang serat, banyak perekat dan intereaksi antara panjang serat-banyak perekat terhadap keteguhan patah, maka dilakukan analisis ragam. Dari analisis ragam tersebut menunjukkan tidak ada pengaruh (signifikan) panjang serat dan banyak perekat tetapi intereaksi keduanya berbeda nyata (signifikan) terhadap keteguhan patah. Hasil Uji lanjut Post Hoc Test (uji beda nyata) intereaksi ukuran serat dan banyak perekat tercantum dalam Tabel 10. 


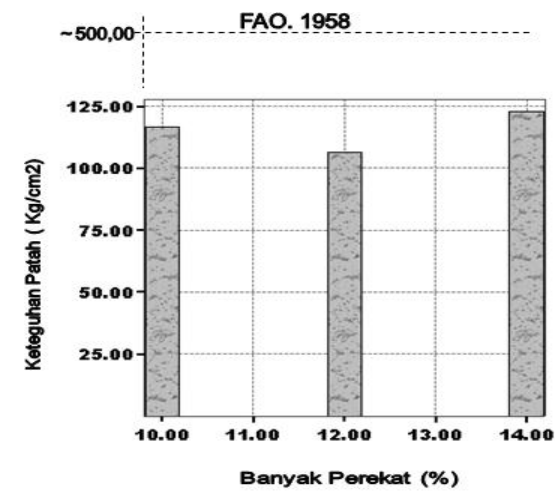

Gambar 6b. Grafik intereaktif variabel banyak perekat keteguhan patah/MOR papan komposit

Tabel 10. Perbedaan panjang serat dan banyak perekat dalam mempengaruhi keteguhan patah.

\begin{tabular}{|c|c|c|c|}
\hline \multirow[b]{2}{*}{ Panjang Serat } & \multicolumn{3}{|c|}{ Banyak Perekat } \\
\hline & B1 $(10 \%)$ & B2 (12\%) & B3 (14\%) \\
\hline \multirow[t]{2}{*}{$\mathrm{Al}(3 \mathrm{~cm})$} & $114,09 \mathrm{~d}$ & $79,81 \mathrm{~d}$ & $135,34 \mathrm{~d}$ \\
\hline & B & A & C \\
\hline A2 (5cm) & $84,42 \mathrm{c}$ & $88,90 \mathrm{c}$ & $157,95 \mathrm{c}$ \\
\hline \multirow[t]{2}{*}{$\mathbf{A 3}(7 \mathrm{~cm})$} & $\underset{125,21 \mathrm{~b}}{\mathrm{~B}}$ & $\underset{112,04 \mathrm{~b}}{\mathrm{~A}}$ & $\begin{array}{c}\text { C } \\
94,87 \text { b }\end{array}$ \\
\hline & B & A & C \\
\hline $\mathrm{A4}(9 \mathrm{~cm})$ & $142,26 \mathrm{a}$ & 144,41 a & $\begin{array}{c}103,92 \mathrm{a} \\
\mathrm{C}\end{array}$ \\
\hline
\end{tabular}

Dari Tabel 10. memperlihatkan keteguhan patah papan komposit tertinggi terdapat pada ukuran serat ( 9 $\mathrm{cm})$ dan banyak perekat $(88,2 \mathrm{~g})$. Hal ini disebabkan karena semakin panjang ukuran serat dan semakin banyak perekat yang diberikan akan memberikan pengaruh yang besar tarhadap keteguhan patah papan partikel yang dihasilkan. Menurut Lehman (1974) cit Hafizul (2002), panjang dan tebal partikel mempunyai pengaruh yang besar terhadap kekuatan papan komposit. Widarmana, 1977 cit Supiana (1995), mengemukakan bahwa penambahan kadar perekat akan memperbaiki sifatsifat papan komposit antara lain keteguhan patah. Selanjutnya semakin besar jumlah perekat yang digunakan maka semakin baik pula keteguhan patah papan pertikel dalam keadaan seimbang berdasarkan tegangan sampai patah. Sifat yang dimaksud adalah tingkat keteguhan papan komposit dalam menerima beban tegak lurus terhadap permukaan papan partikel. Semakin tinggi kerapatan partikel penyusunnya maka akan semakin tinggi pula sifat keteguhan papan partikel yang dihasilkan (Haygreen dan Bowyer, 1989). Lebih banyak perekat yang digunakan, papan partikel akan lebih kuat dan memiliki dimensi yang stabil. Untuk alasan ekonomis, perekat tidak dipakai dalam jumlah yang banyak, artinya hanya dibutuhkan menurut keperluan untuk memperoleh sifat yang dikehendaki (Haygreen dan Bowyer, 1989). Pada dasarnya sifat papan komposit di pengaruhi oleh bahan baku pembetuknya, perekat dan formulasi yang digunakan serta proses pembuatan papan komposit tersebut mulai dari persiapan bahan baku, pembentukan partikel hingga 
pengempaan dan pengkilapan

(Kollmann et al, 1984).

\section{Keteguhan Tekan Sejajar}

\section{Permukaan Papan komposit}

Dari hasil pengujian terhadap keteguhan tekan sejajar permukaan rata-rata papan partikel sabut kelapa berkisar antara $\left(121,77 \mathrm{~kg} / \mathrm{cm}^{2}\right.$ sampai 202,04 $\mathrm{kg} / \mathrm{cm}^{2}$ ), nilai keteguhan tekan sejajar permukaan tertinggi terdapat pada panjang serat $(7 \mathrm{~cm})$ dan banyak perekat $(10 \%)$. Nilai keteguhan tekan sejajar permukaan terendah terdapat pada panjang serat $3 \mathrm{~cm}$ dan banyak perekat $(10 \%)$. Namun secara umum nilai rata-rata keteguhan tekan sejajar permukaan tertinggi terdapat pada panjang serat $(9 \mathrm{~cm})$. Rata-rata keteguhan tekan sejajar permukaan terlihat dalam Tabel 11. dan lebih dijelaskan dengan grafik seperti yang terdapat dalam Gambar 7a dan 7b.

Tabel 11. Nilai rata-rata keteguhan tekan sejajar permukaan papan partikel dari sabut kelapa, pada ukuran panjang serat dan banyak perekat yang berbeda $\left(\mathrm{kg} / \mathrm{cm}^{2}\right)$.

\begin{tabular}{lccc}
\hline \multirow{3}{*}{ Panjang Serat } & \multicolumn{3}{c}{ Banyak Perekat } \\
\cline { 2 - 4 } & B1 $(10 \%)$ & B2 $(12 \%)$ & B3 $(14 \%)$ \\
\hline Al $(3 \mathrm{~cm})$ & 121,77 & 138,30 & 173,00 \\
A2 $(5 \mathrm{~cm})$ & 158,69 & 135,78 & 149,96 \\
A3 $(7 \mathrm{~cm})$ & 202,04 & 162,84 & 152,82 \\
A4 $(9 \mathrm{~cm})$ & 172,12 & 175,63 & 197,07 \\
\hline
\end{tabular}

Apabila dibandingkan dengan standar FAO (1958), maka semua nilai keteguhan tekan sejajar permukaan yang diperoleh telah memenuhi standar tersebut, karena FAO ( 1958) mensyaratkan nilai keteguhan tekan sejajar permukaan $\left(100-200 \mathrm{~kg} / \mathrm{cm}^{2}\right)$ dan SNI (1996) (tidak disyaratkan).

Untuk mengetahui pengaruh panjang serat, banyak perekat dan intereaksi antara panjang serat-banyak perekat terhadap keteguhan tekan sejajar permukaan, maka dilakukan analisis ragam. Dari analisis ragam tersebut menunjukkan tidak ada pengaruh

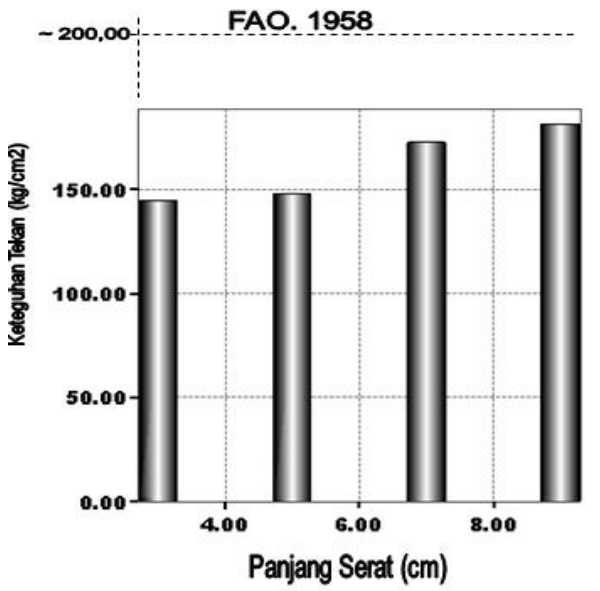

Gambar7a.Grafik intereaktif variabel panjang sabut keteguhan tekan sejajar permukaan papan komposit.

(signifikan) panjang serat, banyak perekat dan intereaksi keduanya terhadap keteguhan tekan sejajar permukaan. 


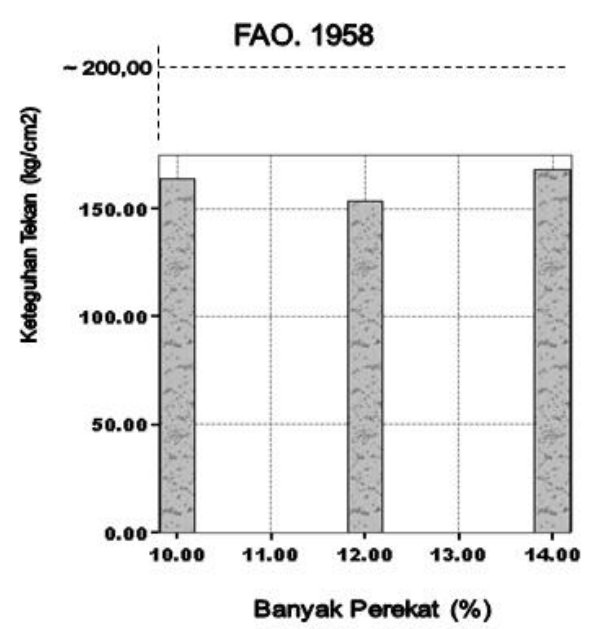

Gambar7b. Grafik intereaktif variabel banyak perekat keteguhan tekan sejajar permukaan papan komposit.

Hal ini disebabkan karena dengan semakin panjangnya ukuran serat yang seragam dan banyaknya perekat yang digunakan akan memberi pengaruh yang besar terhadap kekuatan papan komposit. Untuk alasan ekonomis, perekat tidak dipakai dalam jumlah yang banyak, artinya hanya dibutuhkan menurut keperluan untuk memperoleh sifat yang dikehendaki (Haygreen dan Bowyer, 1989).

\section{Keteguhan rekat internal}

\section{(Internal- Bond/IB)}

Dari hasil pengujian terhadap keteguhan rekat internal rata-rata papan komposit serat sabut kelapa berkisar antara $\left(9,61 \mathrm{~kg} / \mathrm{cm}^{2}\right.$ sampai $17,85 \mathrm{~kg} / \mathrm{cm}^{2}$ ), nilai keteguhan rekat internal tertinggi terdapat pada panjang serat $(9 \mathrm{~cm})$ dan banyak perekat (14\%). Nilai keteguhan rekat internal terendah terdapat pada panjang serat $(3 \mathrm{~cm})$ dan banyak perekat (12\%). Rata-rata keteguhan rekat internal terlihat dalam Tabel 12. dan lebih dijelaskan dengan grafik seperti yang terdapat dalam Gambar 8 .

Tabel 12. Nilai rata - rata keteguhan rekat internal papan komposit dari sabut kelapa, pada ukuran panjang serat dan banyak perekat yang berbeda $\left(\mathrm{kg} / \mathrm{cm}^{2}\right)$.

\begin{tabular}{lccc}
\hline \multirow{3}{*}{ Panjang Serat } & \multicolumn{3}{c}{ Banyak Perekat } \\
\cline { 2 - 4 } & Bl $(10 \%)$ & B2 $(12 \%)$ & B3 $(14 \%)$ \\
\hline Al $(3 \mathrm{~cm})$ & 12,49 & 9,61 & 11,42 \\
A2 $(5 \mathrm{~cm})$ & 14,43 & 10,93 & 9,69 \\
A3 $(7 \mathrm{~cm})$ & 11,02 & 16,55 & 12,71 \\
A4 $(9 \mathrm{~cm})$ & 15,06 & 10,78 & 17,85 \\
\hline
\end{tabular}

Sumber : Hasil Analisis

Apabila dibandingkan dengan standar SNI (1996), maka nilai keteguhan rekat internal yang diperoleh semuanya telah memenuhi standar tersebut, karena SNI (1996) mensya- ratkan nilai keteguhan rekat internal minimum $\left(6 \mathrm{~kg} / \mathrm{cm}^{2}\right)$ sedangkan FAO (1958) mensyaratkan nilai keteguhan rekat internal (2 $\left.\mathrm{kg} / \mathrm{cm}^{2}\right)$ sampai dengan $\left(12 \mathrm{~kg} / \mathrm{cm}^{2}\right)$

Untuk mengetahui pengaruh panjang sabut, jumlah perekat dan intereaksi antara panjang serat-banyak perekat terhadap keteguhan rekat internal, maka dilakukan analisis 
ragam. Dari analisis ragam tersebut menunjukkan tidak ada pengaruh (signifikan) panjang serat, banyak perekat dan intereaksi keduanya terhadap keteguhan rekat internal, tetapi berdasarkan data yang diperoleh pada Tabel 12. terlihat semakin panjang ukuran serat $(\sim 9 \mathrm{~cm})$ dengan banyak perekat (10\%) menghasilkan nilai keteguhan rekat internal yang tinggi pada papan partikel yang dibuat dari serat sabut kelapa.

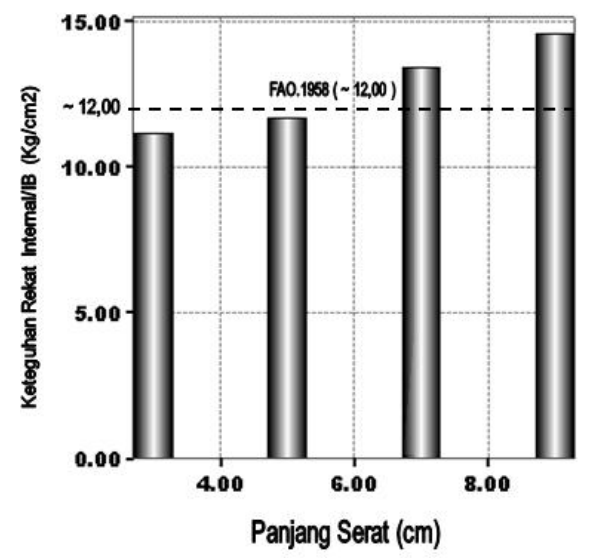

Gambar8a.Grafik intereaktif variabel panjang sabut keteguhan rekat internal papan komposit

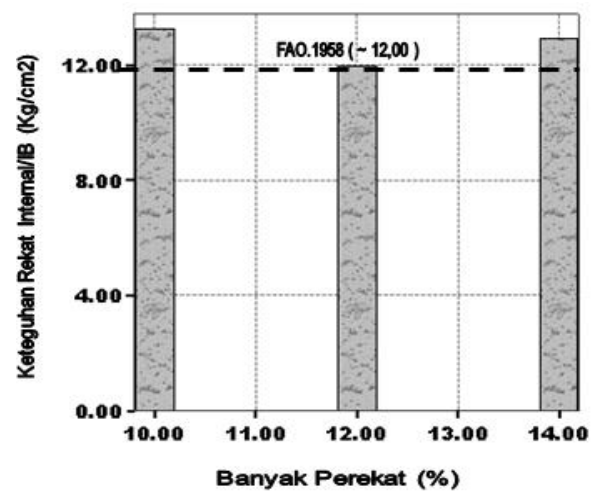

Gambar 8b. Grafik intereaktif variabel banyak perekat keteguhan rekat internal papan komposit
Dengan demikian semakin panjang ukuran serat yang seragam dan penggunaan perekat yang yang sedikit (10 \%) dari berat kering serat akan memberi pengaruh yang besar terhadap keteguhan rekat internal papan komposit. Widarmana (1977) mengatakan bahwa keseragaman ukuran dan bentuk partikel menentukan kekuatan papan komposit. Partikel yang lebar dan panjang dengan pemakaian perekat yang rendah merupakan ciri khas dari papan komposit.

\section{Pelapisan Melamin Formaldehide}

\section{Papan Partikel}

Papan komposit yang telah memenuhi standar, selanjutnya dilakukan pelapisan dengan lapisan melamin formaldehide agar kelihatan mengkilap, lebih bercorak, datar dan licin. Lapisan melamin formaldehide sesuai dengan ketentuan digunakan berdasarkan berat labur. Berat labur yang digunakan yaitu berkisar antara (190 - 200) g/m², (Pasrul. 1991). Dalam penggunaan papan komposit ada beberapa keuntungan yang diperoleh antara lain adalah: (1) Merupakan bahan konstruksi yang cukup kuat, (2) Bahan isolasi dan 
akustik yang baik, (3) Dapat menghasilkan bidang yang luas, (4) Pengerjaan mudah dan cepat, (5)

Memiliki kestabilan dimensi, (6) Mudah difinishing, dilapisi kertas dekor, dilapisi finir dan sebagainya, (7) Tahan api (Dumanauw, 2001).

Setelah dilakukan percobaan pelapisan yaitu dengan berat labur $\left(194,5\right.$ - 196,5 - 200) $\mathrm{g} / \mathrm{m}^{2}$ ternyata dari pengamatan yang dilakukan papan komposit yang kelihatan mengkilap, bercorak, datar dan licin diperoleh pada penggunaan melamin formaldehide $\left(200 \mathrm{~g} / \mathrm{m}^{2}\right)$.

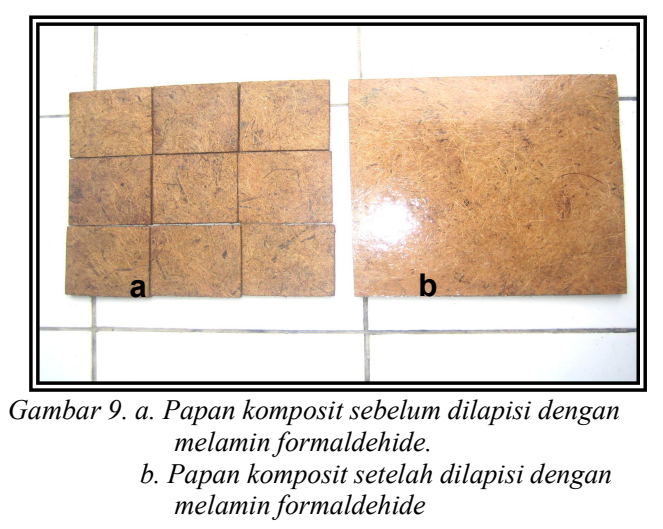

Disamping kelihatan bercorak, datar dan licin serta mengkilap lapisan melamin formaldehide transparan pada permukaan papan partikel sehingga susunan serat sabut kelapa memberi kesan dekoratif.

Perbedaan papan komposit yang belum dilapisi dengan yang sudah dilapisi dengan Melamin
Formaldehide dapat terlihat dalam Gambar 9 dan 10.

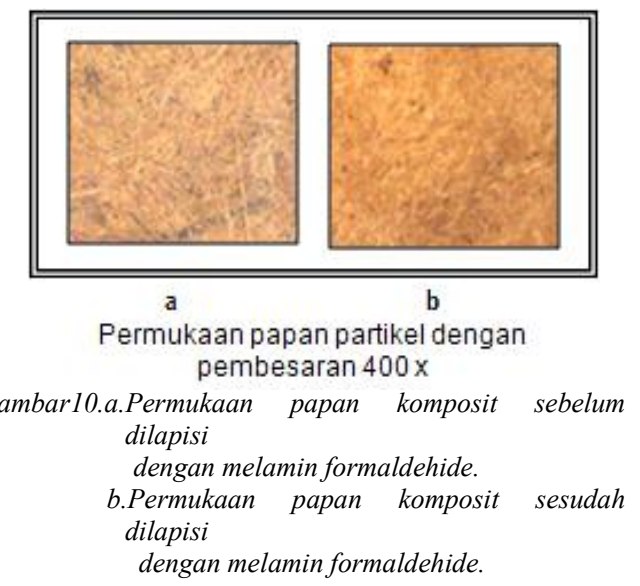

Papan komposit yang belum dilapisi dengan melamin formaldehide masih terlihat buram tampilan serat masih kasar sedangkan untuk papan partikel yang telah dilapisi dengan melamin formaldehide kelihatan mengkilap, lebih bercorak, datar dan licin serta transparan dengan susunan serat sabut kelapa terkesan dekoratif. Berdasarkan perlakuan tersebut lebih banyak melamin formaldehide yang digunakan, papan komposit akan lebih bercorak dan memiliki dimensi yang stabil, namun untuk alasan ekonomis melamin formaldehide tidak dipakai dalam jumlah yang banyak, artinya hanya dibutuhkan menurut keperluan untuk memperoleh penampilan yang dikehendaki. Menurut Kollmann et al, (1984) mengemukakan pada dasarnya sifat papan komposit di pengaruhi 
oleh bahan baku pembetuknya, perekat dan formulasi yang digunakan serta proses pembuatan papan komposit tersebut mulai dari persiapan bahan baku, pembentukan partikel hingga pengempaan dan pengkilapan.

\section{KESIMPULAN}

\section{Kesimpulan}

Berdasarkan hasil penelitian yang telah dilakukan tentang pembuatan papan komposit termoset serat sabut kelapa dengan menggunakan sabut kelapa, dapat ditarik kesimpulan sebagai berikut :

1. Panjang serat sabut kelapa yang paling cocok untuk membuat papan komposit adalah $(9 \mathrm{~cm})$.

2. Banyaknya perekat urea formaldehide $(10 \%)$ dari berat kering serat.

Berdasarkan hasil penelitian tersebut dinyatatakan bahwa papan komposit yang dihasilkan telah memenuhi standar SNI (1996), dan FAO. 1958. .

\section{DAFTAR PUSTAKA}

"SNI (1996). Standar Nasional Indonesia -Papan Partikel Datar", SNI. 03. 2105. Dewan Standarisasi Nasional.
Bank Indonesia, (2002), "Produksi Kelapa", Sistim Informasi Pengembangan Usaha Kecil. Jakarta

Dumanauw, J. F (1882), "Mengenal Kayu", Edisi Pertama. Gramedia Jakarta.

FAO (1958), "Fibre Board and Particle Board", Food and Agriculture Organitation of The United Nations.

Haygreen, J. G dan Bowyer, J. L (1989), "Hasil Hutan dan Ilmu Kayu Suatu

Pengantar", diterjemahkan oleh Dr. Ir. Sucipto. A Hadikusuma. Gajah Mada Univ. Press. Yogyakarta.

Hafizul (2002), "Pengaruh Ukuran Partikel Dan Bahan Baku terhadap Sifat Fisis Dan Mekanis Papan Partikel Dari Rotan (calamus sp)", skripsi Fakultas Kehutanan UMSB. (Tidak dipublikasikan).

Kasim. A (2003), "Penuntun Praktikum Pemanfaatan Limbah Agro Industri”

Program Studi Ilmu Lingkungan Pasca Sarjana Universitas Andalas.

Kasim. M (1997), "Pedoman Penulisan Proposal Penelitian dan Tesis" Pasca Sarjana Universitas Andalas.

Kollman. F. P. A, E.W. Kuenji, and A.J. Stamm, (1975 \& 1984), "Prinsiples of Wood Science and Tecnology II. Spring Verlag, Berlin.

Lasmini, (1982), "Pengaruh Penambahan Bahan Pengawet Tindane Terhadap Sifat - Sifat Fisik \& Mekanik Papan Partikel Kayu Karet (havea brasiliensis 
Muellarg)", Thesis Teknologi Hasil Hutan IPB. Tidak dipublikasikan.

Maloney, T. M, (1977), "Modern Particle Board And Dry Process Fiberboard", Manufacturing Miller - Fremann Publication San Fransisco.

Pratisto A, (2004), “Cara Mudah Mengatasi Masalah Statistik dan Rancangan Percobaan dengan SPSS 12" Penerbit PT Elex Media Koputindo Kelompok Gramedia, Jakarta.

Supiana . A (1995), "Pengaruh Laminasi dan Kadar Perekat UF terhadap Kualitas Papan Partikel Limbah Industri Pengolahan Sagu (metroxylen spp)", Sripsi Jur. Teknologi Hasil Pertanian IPB. Tidak dipublikasikan.

Thieme, J. G. (1968), “Coconut Oil Processing". FAO Agricultural Dev. Paper. No. 80. Rome : Food and Agriculture Organitation.

Widarmana, . (1977), "Panil-Panil Berasal Dari Kayu Sebagai Bahan Bangunan ".Proseding Seminar Persaki di Bogor 23-24 Juni 1977. (Pengurus pusat Persaki Bogor).

Yuliasari, . (2003), "Karakteristik Limbah Kelapa Sawit dan Pemanfaatanya Sebagai Bahan Baku Papan Partikel". Proseding Seminar Teknologi Untuk Memacu Pertumbuhan Agroindustri Tanaman Perkebunan dan Peningkatan Ketahanan Pangan, Universitas Andalas 2003. 
122 |Jurnal Pembangunan Nagari/Volume 2 Nomor 2 Edisi Desember 2017 : 103 - 122 